УДК 621.165

Швецов В.Л., Гришин М.М.

Акціонерне товариство «Турбоатом». Україна, м. Харків

\title{
СТВОРЕННЯ РОТОРІВ ТУРБІН ВЕЛИКОЇ ПОТУЖНОСТІ
}

Розглянуті науково-технічні основи створення та впровадження конструкцій надійних в експлуатації високоефективних роторів турбін великої потужності нового покоління, як готових закінчених виробів з високою науково-технічною і інновачійною складовою, які можуть бути використані як при модернізації діючих турбоагрегатів, так і при поставці нових паротурбінних блоків потужністю 100-1250 МВт на ТЕС і АЕС України, а також на експорт. Конструкиї створених роторів за своїми техніко-економічними показниками, показниками надійності $і$ безпеки відповідають кращим світовим зразкам. [dx.doi.org/10.29010/087.1]

Ключові слова: парова турбіна; иільноковані ротори; комбіновані зварні ротори; міщність; турбоагрегат; коротке замикання; валопровід; модернізація; стенд зварювання.

\section{Вступ}

Однією з найважливіших складових національної безпеки нашої держави є стійке, стабільне та високоефективне функціонування паливно-енергетичного комплексу України.

Поточний рівень виробництва електроенергії (близько 164 млрд кВт·год в рік) ще досить суттєво відстає від планових показників, які зазначені в Енергетичній стратегії України на 2035-й рік (195 млрд кВт·год в рік.) [1].

Одним з найбільш дієвих і реальних напрямів розв'язання задач підвищення виробництва електроенергії та суттєвого підвищення ефективності обладнання паливно-енергетичного комплексу України може бути розгортання робіт з масштабної заміни та модернізації застарілого обладнання теплових і атомних електростанцій на сучасне високоефективне обладнання. Це стосується і діючого парку парових турбін атомних електричних станцій (AEC) та теплових електричних станцій (ТЕС). В даний час Акціонерне товариство (AT) «Турбоатом» і інститути наукових та навчальних центрів України в галузі турбінобудування (НTУ «XПI», IE3 ім. Є. О. Патона НАН України та ІПМаш ім. А.М. Підгорного НАН України), виконують роботи по великому обсягу модернізації турбін АЕC і TEC України і, зокрема, модернізації роторів і елементів роторів - робочих лопаток.

Ротори циліндрів є одними з найбільш навантажених і відповідальних вузлів парових турбін, безвідмовна робота яких визначає ї потужність, надійність і довговічність, а також безпеку експлуатації теплових та атомних електростанцій.
3 урахуванням сучасних вимог до безпеки АЕC або ТЕС, необхідністю постійного вдосконалення конструкцій турбін, проблема розробки нових, науково обгрунтованих методів проектування i методик для підвищення конструктивної міцності роторів турбін, вироблених АТ «Турбоатом», є актуальною в науковому та практичному відношеннях.

У статті наведені результати основних науковотехнічних розробок і досягнень, пов'язаних з розв'язанням проблем проектування, конструювання та технологічного супроводу виробництва і особливостей експлуатації турбін з роторами нового покоління [2].

\section{Енергетичний комплекс України та використання його потенціалу}

для реалізації енергетичної стратегії України на період до 2035 року

Згідно з Програмою участі АТ «Турбоатом» у поставках обладнання для АЕС України на п'ятирічний період (2018-2022рр.) [3], необхідно виконати модернізацію проточних частин циліндрів парових турбін типу К-220-44, К-1000-60/1500, К-1000-60/3000 з заміною робочих лопаток роторів, або з заміною самих роторів. У найближчі роки необхідно закінчити модернізацію парових турбін на теплових електростанціях України.

На території України розташовані:

14 великих ТЕС $з$ блоками одиничної потужності 200 МВт (43 блоки), 300 МВт (42 блоки), 800 МВт (7 блоків), 160 МВт (6 блоків), 100 МВт (3 блоки), 80 МВт (1 блок), які введені в експлуа- 
тацію з 1957 року по 1977 рік: Добротвірська, Бурштинська, Ладижинська, Трипільська, Криворізька, Запорізька, Придніпровська, Зміївська, Слов'янська, Луганська, Вуглегірська, Курахівська, Зуївська та Старобешівська;

4 AEC 3 блоками одиничної потужності 440 МВт (2 блоки), 1000 МВт (12 блоків), 1100 МВт (1 блок), які введені в експлуатацію 3 1980 по 2005 рік: Южно-Українська, Запорізька, Рівненська та Хмельницька.

На атомних елетростанціях перші турбіни блоків потужністю 440 МВт знаходяться в експлуатації 38 років, перші турбіни блоків потужністю 1000 МВт - 36 років при терміні служби 30 років. Глибока модернізація турбін виконана на Рівненській АЕС із заміною роторів низького тиску. Передбачена модернізация цилиндрів високого та середнього тиску з заміною роторів на Южно-Українській AEC, та цилиндрів високого тиску з заміною роторів на Запорізькій, Хмельницькій та Рівненській АЕС.

Починаючи з 2005 року протягом 13 наступних років AТ «Турбоатом» виконував роботи по модернізації 22 блоків парових турбін на 8 теплових електростанціях України. При модернізації на ряді турбін було замінено близько 20 роторів старої конструкції на сучасні зварні ротори.

Будівництво нових енергоблоків є досить затратним і тривалим проектом. У той же час модернізація наявних потужностей на ТЕC і АЕC, яка є меншим за масштабом проектом, може виконуватися поступово, що вимагає менших коштів та дозволяє скористатися наявною інфраструктурою. Значний приріст електричної потужності на електростанціях може бути досягнутий модернізацією основного і допоміжного обладнання турбоустано- вок. В Україні таке обладнання виробляє підприємство - АТ «Турбоатом», що дозволяє однозначно зменшити імпортну залежність необхідних проектів 3 модернізації обладнання атомних і теплових електростанцій.

\section{Парові турбіни українського заводу - виробника}

Позитивний досвід проектування i виготовлення парових турбін та досвід тісної співпраці AT «Турбоатом» 3 провідними науково-дослідними i навчальними інститутами України, дозволили створити і відвантажити на TEC і AEC близько 600 парових турбін великої потужності різного конструктивного виконання. АТ «Турбоатом» $\mathrm{E}$ одним 3 найбільших постачальників на світовому ринку парових турбін одиничною потужністю від 2 до 1100 МВт для теплових і атомних електростанцій. Перша турбіна потужністю 50 МВт виробництва Харківського турбогенераторного заводу була введена в експлуатацію на тепловій електростанції України в 1935 році. У 1950 році підприємство приступило до проектування, в 1956 році виготовило і в 1958 році запустило в експлуатацію першу парову турбіну потужністю 30 МВт на атомній станції. Одна з останніх турбін виробництва AT «Турбоатом» одиничною потужністю 1100 МВт прийнята в експлуатацію на АЕС в 2018 році.

Виконана розробка тихохідної парової турбіни К-1250-6.9/25 одиничної потужності 1250 МВт в трьохциліндровому виконанні з робочою лопаткою останнього ступеню 1750 мм (рис. 1). Коефіцієнт корисної дії блоку з турбіною новітньої розробки становить величину $38 \%$. Технічні характеристики турбіни 3 маркою АТ «Турбоатом» відповідають даним турбін провідних світових виробників.

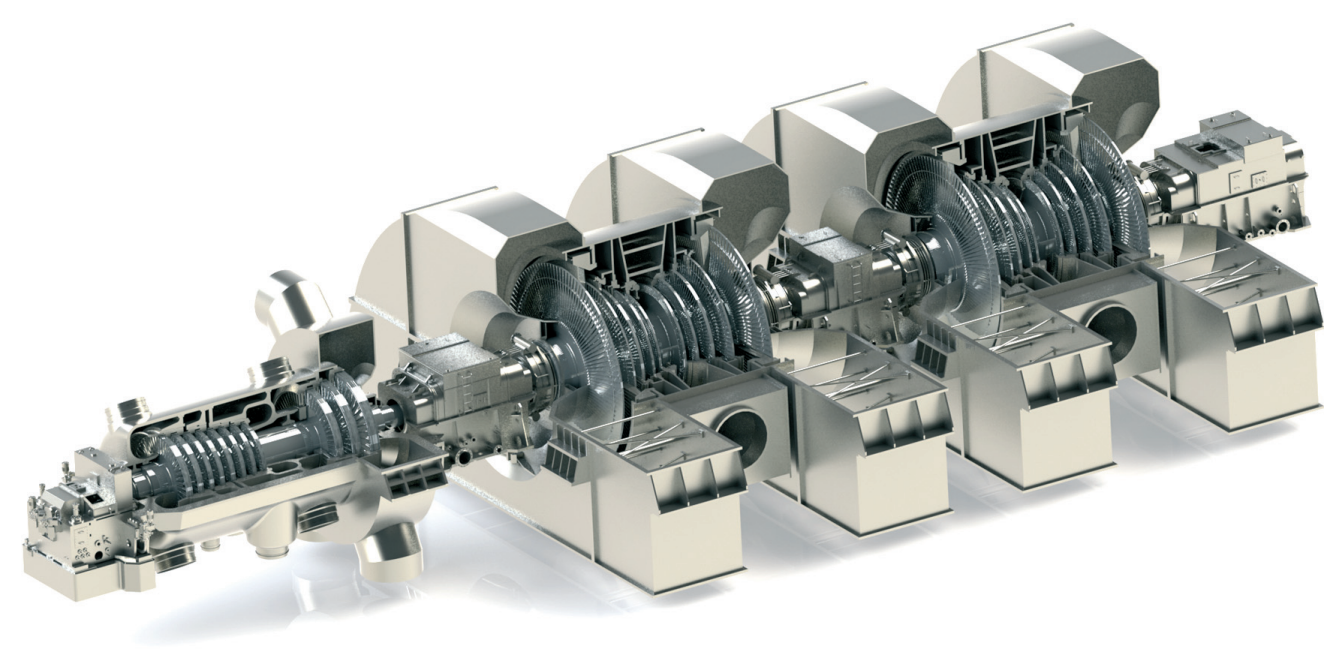

Рис. 1. Циліндри зі зварними роторами парової турбіни К-1250-6.9 / 25 
Під проточну частину 3 робочою лопаткою останнього ступеню 1750 мм спроектований зварний ротор низького тиску (НТ) граничних габаритів. Ротор суміщеного циліндра високого і середнього тисків прийнятий зварної конструкції.

Підприємство поставляє парові турбіни наступних основних типів: конденсаційні типу К, теплофікаційні з виробничим і опалювальним відборами пари типу ПТ, конденсаційні з відпуском тепла на теплофікацію типу КТ, теплофікаційні з протитиском, без регульованого відбору пари типу Р.

Конденсаційні парові турбіни. Основним типом парових турбін, виготовлених на АТ «Турбоатом», є конденсаційні парові турбіни для теплових і атомних електростанцій на різні параметри пари. Для теплових електростанцій виготовлені турбіни з найбільшою потужністю 540 МВт, на наступні номінальні параметри пари: температура свіжої пари становить величину $540^{\circ} \mathrm{C}$, тиск свіжої пари 23,5 МПа. Для атомних електростанцій виготовлена конденсаційна парова турбіна граничною потужністю 1100 МВт.

Конденсаційні парові турбіни успішно експлуатуються в Україні, Фінляндії, Угорщині, Болгарії, Вірменії, Індії, Китаї, Північній Кореї, Узбекистані, Кубі та інших, що підтверджує правильний підхід до виконання робіт 3 проектування та при виробництві турбін.

Турбіни теплофікаційні з виробничим і опалювальним відборами пари, конденсаційні з відпуском тепла на теплофікацію. В АТ «Турбоатом» накопичено позитивний досвід проектування і виготовлення теплофікаційних парових турбін з відборами пару, або відпуском тепла. У 2002 році виготовлена турбіна ПТ-20-2,9/1,0, у 2006 році ПТ-35-2,9/0,8/0,12 з регульованими виробничим і теплофікаційним відборами. Для теплопостачання промислових та соціально-побутових споживачів є розробки парових турбін П-6-3.4/0.5, ПТ-12/15-3.4/0.8/0.12, ПТ-258.8/1.0/0.12, КТ-125/115-12.8 та ін.

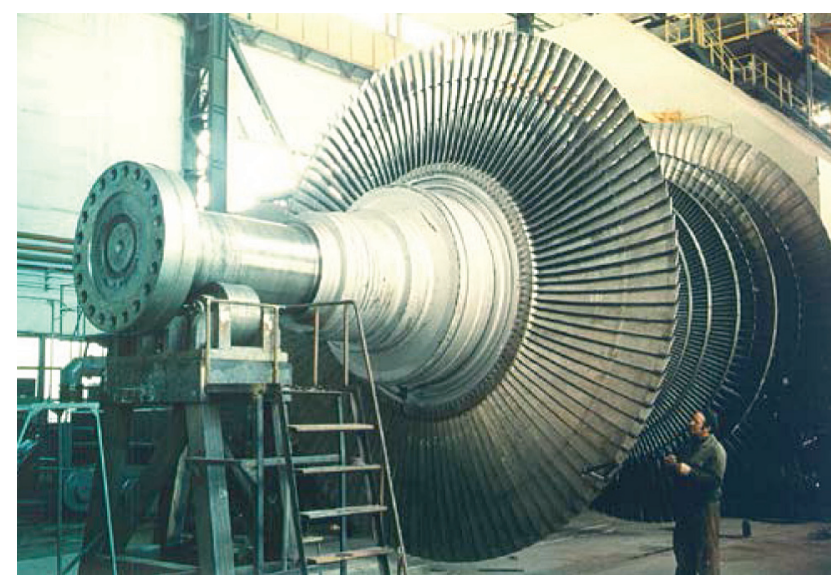

Рис. 2. Ротор низького тиску «тихохідних» турбін типу К-1000-60/1500
Турбіни теплофікаційні з протитиском, без регульованого відбору пари. Першу серію турбін 3 протитиском потужністю 25 МВт АТ «Турбоатом» вперше розробив і виготовив в кінці 40-их років минулого століття. Особлива увага 3 ряду даного типу турбін заслуговує турбіна потужністю 100 МВт, виготовлена в 1962 році на зверхкритичні параметри свіжої пари: температура свіжої пари становила величину 6500С, тиск свіжої пари 29,4 МПа. Провідні світові турбобудівні фірми тільки в даний час проектують парові турбіни на наведені високі параметри пари.

Як при будівництві нових електростанцій малої потужності, так і для заміни тих що відпрацювали ресурс турбін на діючих, АТ «Турбоатом» випускає сучасні парові протитискові турбіни потужністю 2-12 МВт. Відібраний редуцьований пар з турбін використовується для технологічних потреб підприємств переробної, харчової, металургійної, хімічної промисловості та комунального господарства. До теперішнього часу в цехах підприємства виготовлено понад п'ятдесят турбін малої потужності з протитиском.

\section{Типи роторів парових турбін, використовувані матеріали, переваги зварних роторів}

Як було зазначено раніше, ротори парових турбін в зборі з робочими лопатками (рис. 2 і 3) в значній мірі визначають економічність і безпеку роботи не тільки паротурбінних установок, але і TEC або AEC в цілому. При таких жорстких вимогах залишаються актуальними питання правильного вибору типу ротора, який визначається умовами експлуатації і можливістю забезпечення міцності. Для їх вирішення необхідні нові підходи до створення роторів, засновані на даних тривалого досвіду їх проектування і експлуатації, технології виготовлення, ремонтів і модернізації.

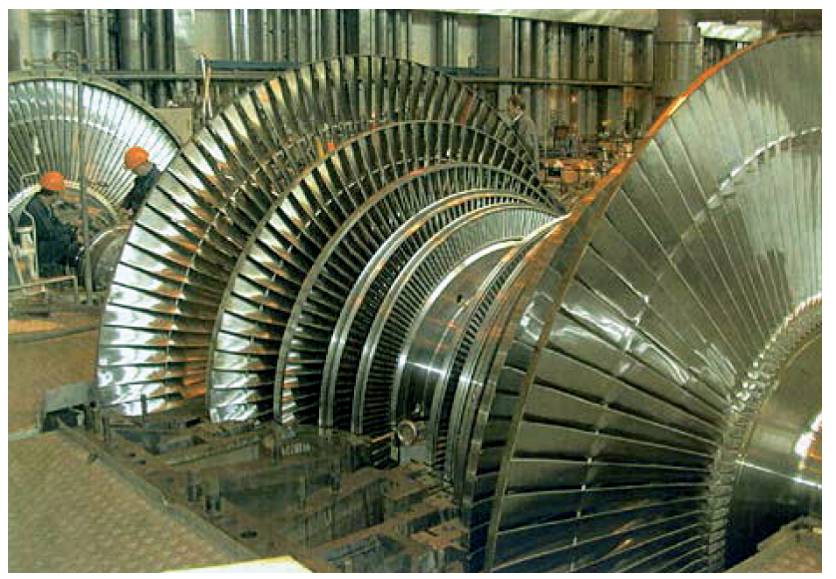

Рис. 3. Ротор низького тиску «швидкохідних» турбін К-220-44-2 АЕС «Ловііса», Фінляндія 


\section{Ixxonorinutcenn TC $2 / 2019$}

У парових турбінах виробництва АТ «Турбоатом» застосовуються основні типи роторів: цільноковані, комбіновані ротори з насадними дисками, зварні і комбіновані зварні з різних марок сталей.

Цільноковані ротори. Цільноковані ротори складаються 3 валу і дисків виготовлених з однієї поковки (рис. 4). Через складність виготовлення високоякісних поковок великих розмірів, цільноковані ротори мають порівняно невеликі вагові та геометричні характеристики. Даний тип роторів в основному застосовується в циліндрах з високими параметрами пари і має високу технологічність. Цільноковані ротори виробництва АТ «Турбоатом», що працюють при високих температурах, виготовляються зі сталі 20ХЗМВФА (ЭИ-415), що має високі показники жароміцності до температури $550{ }^{\circ} \mathrm{C}$.

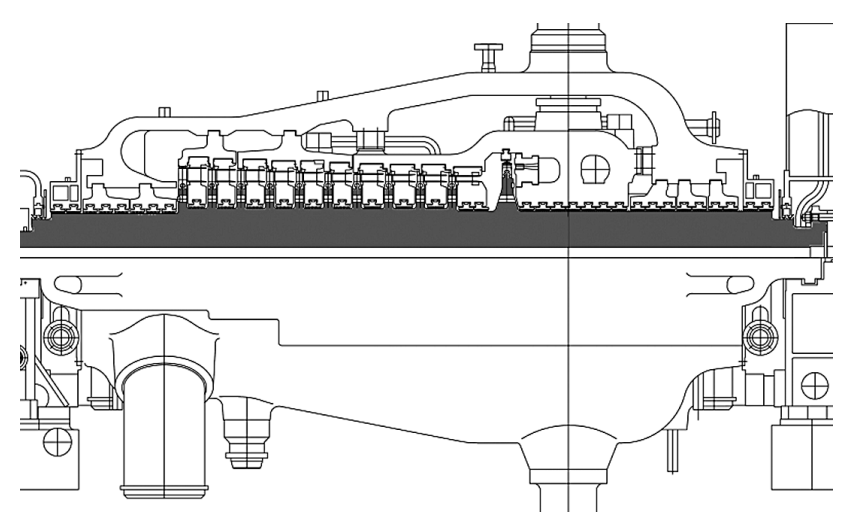

з'єднувальні муфти і інші деталі (рис. 5). Посадка на вал дисків і напівмуфт виконується з натягом. При розрахунку натягу враховується його ослаблення в процесі експлуатації під дією відцентрових сил і температури. При визначенні натягу і виборі розмірів шпоночного з'єднання з метою запобігання провертанню дисків на валу, враховуються різного роду позаштатні ситуації, наприклад коротке замикання генератора. В роторах з насадними дисками використовуються торцеві шпонки.

Комбіновані ротори з насадними дисками можуть працювати тільки при помірних температурах пари, так як при високих температурах пари внаслідок релаксації контактних напружень може відбуватися ослаблення посадки диска на вал. При ослабленні посадки спостерігається розбалансування ротора

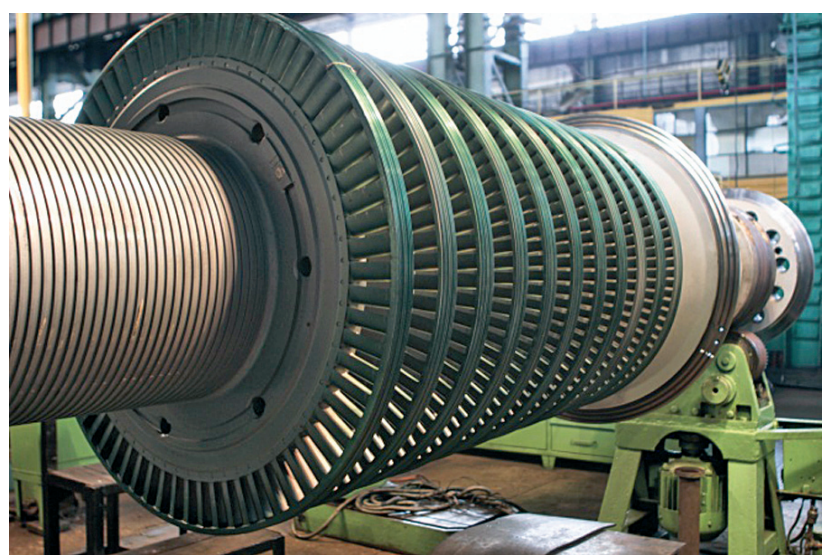

Рис. 4. Цільнокований ротор ВТ турбіни типу К-300-240; ротор ВТ на ділянці облопачування

Для роторів турбін, що працюють при низьких, менше 4500С температурах пари, застосовуються сталі 34ХНЗМА, 36ХНЗМФА, 25Х2Н4МФА і 26ХНЗМ2ФА, 25Х2НМФА за умовами поставки АТ «Тррбоатом».

Комбіновані ротори з насадними дисками. Комбіновані ротори з насадними дисками представляють собою ступінчатий вал, на який насаджуються диски,

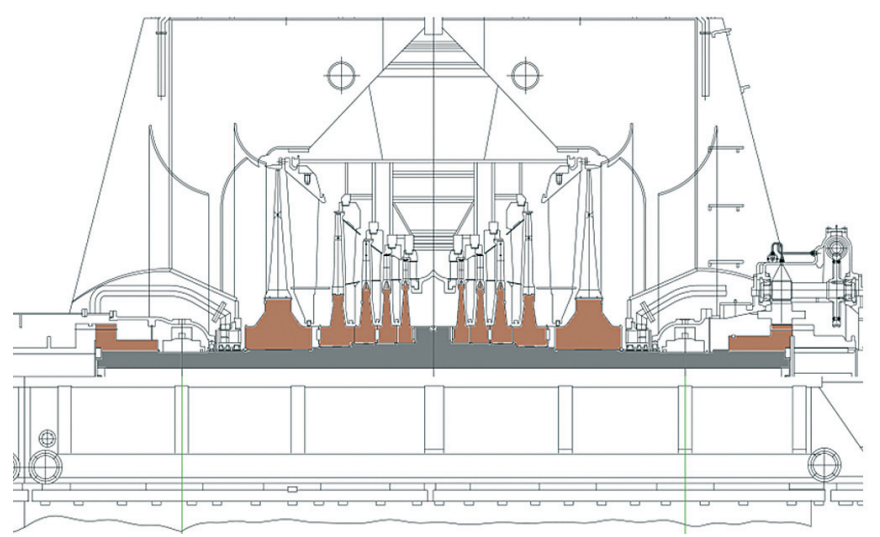

і підвищений рівень вібрації, що порушує подальшу нормальну експлуатацію турбоагрегату. Як матеріали при виготовленні насадних дисків використовуються сталі 34ХН1MА і 25Х2Н4МФА, валу сталь 34ХНЗМА.

Зварні ротори. Зварні ротори, що складаються 3 окремих кованих дисків і хвостовиків, з'єднаних між собою циліндричними перемичками зі зварни-

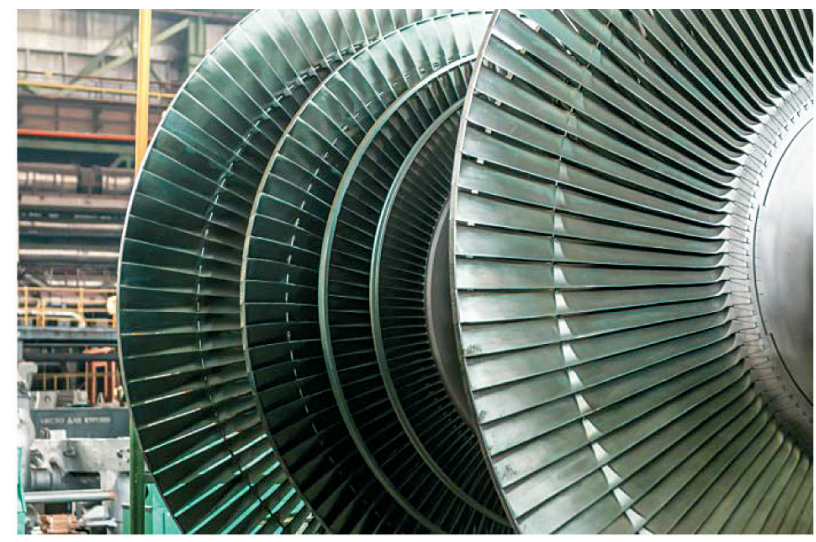

Рис. 5. Ротор НТ турбіни К-300-240 з насадними дисками 
ми швами, знайшли широке застосування в циліндрах низького тиску парових турбін АТ «Турбоатом» $[4,5]$. Перехід до зварних роторів був обумовлений не тільки труднощами виготовлення важких роторів, виконаних як цільнокованими або з насадними дисками, але і рядом інших переваг. Зварні ротори мають велику жорсткість, що сприятливо позначається на стійкості їх роботи, меншу чутливість до виникаючих в експлуатації небалансу і розцентровки, легше піддаються балансуванню. Найбільш напружені частини зварних роторів не схильні до корозії, тому що центральна частина дисків не контактує 3 корозійним середовищем. Максимальні напруження в зварних

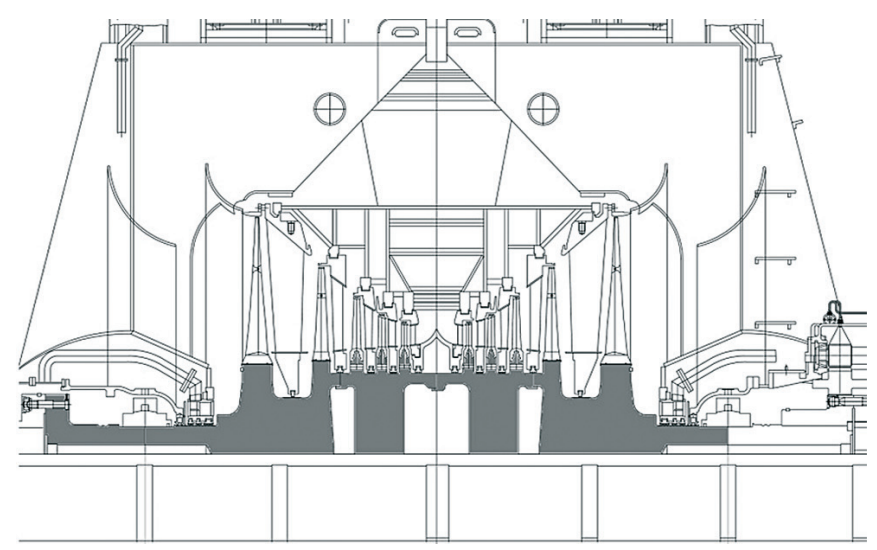

У парових турбінах, що виготовляються АТ «Турбоатом», переважно застосовують зварні ротори НТ двох основних типів, показані на рис. 2 і 3. Зварні ротори «тихохідних» турбін з робочою кутовою швидкістю обертання валопровода 1500 об/хв мають конструкцію, показану на рис. 2. Такий тип конструкції ротора мають турбіни К-500-60/1500, К-1000-60/1500, К-1100-60/15002 М. Зварні ротори для «швидкохідних» турбін 3 робочою кутовою швидкістю обертання валопровода 3000 об/хв мають конструкцію, показану на рис. 3. Такий тип конструкції використаний в турбінах К-220-44, K-320-23.5, K-500-65, K-500-240, К-750-65, К-325-23,5 та інших.

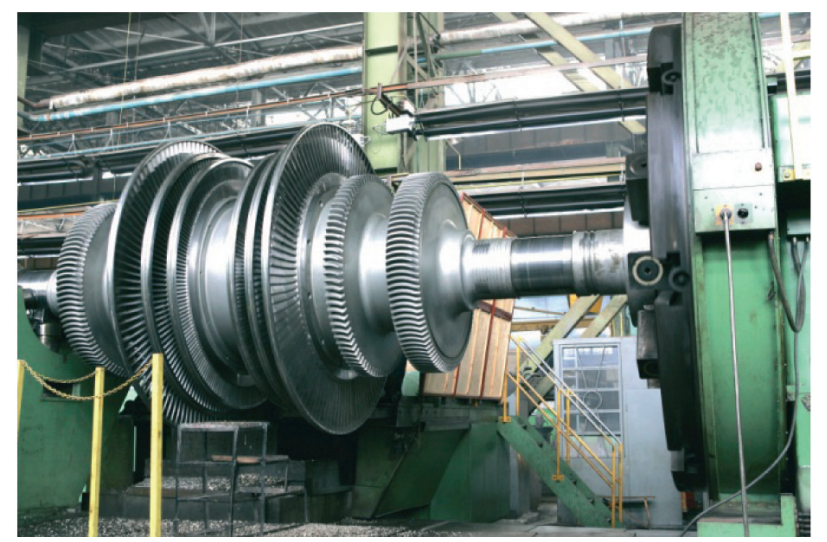

Рис. 6. Зварний ротор НТ турбіни К-325-23,5; механічна обробка зварного ротора

роторах через відсутність центрального отвору в дисках є приблизно в два рази меншими, ніж в насадних дисках і в цільнокованих роторах з центральним каналом.

Відносно невисокі необхідні механічні властивості матеріалу зварного ротора дозволяють отримати кращі пластичні характеристики, велику в'язкість руйнування і більш низькі критичні температури крихкості. Невеликі габарити заготовок зварних роторів дозволяють досягти глибокої проковки дисків, отримати менше металургійних дефектів і чистіший метал, провести якісний контроль дисків до зварювання, відбраковування неякісних дисків і хвостовиків.

Зварні ротори мають високу ремонтопридатність, при ремонті можлива заміна його частин шляхом приварки нових.

Зварні ротори (рис. 6) застосовуються в циліндрах НТ сучасних турбін великої потужності. До теперішнього часу заводом виготовлено та експлуатується понад 550 зварних роторів з сумарним напрацюванням понад 100 млн годин для різних парових (потужністю 100-1100 МВт) і газових турбін. В AT «Турбоатом» було виконано зварювання роторів низького тиску парової турбіни К-1200-240 Ленінградського металічного заводу (ЛМЗ).
Для виготовлення зварних роторів використовуються ковані заготівки дисків, хвостовиків та інших елементів з сталей 25Х2НМФА і 20ХН2МФА, ЭИ-415 (20ХЗМВФА). Заготівки зварних роторів відносяться до групи заготівок 3 індивідуальним визначенням механічних властивостей.

Комбіновані зварні ротори з різних марок сталей. Починаючи 32005 р. на АТ «Турбоатом» почали активно опрацьовуватися питання виготовлення комбінованих («композитних») зварних роторів 3 різних легованих конструкційних сталей (рис. 7). В циліндрах середнього тиску турбін нового покоління потужністю 325 МВт замість застарілих комбінованих роторів з насадними дисками необхідно було застосувати сучасні комбіновані зварні ротори з різних марок сталей, що мають переваги перед першими. Для частини середнього тиску, що працює в високотемпературному режимі, використовувалася сталь ЭИ-415, а для частини низького тиску, що працює в низькотемпературному режимі, використовувалася сталь 25Х2НМФА.

За останні п'ять років в АТ «Турбоатом» виготовлено 5 «композитних» роторів, виконаних з різних марок сталей (рис. 7). При виробництві та експлуатації підтвердилися переваги зварнокованих «композитних» роторів. 

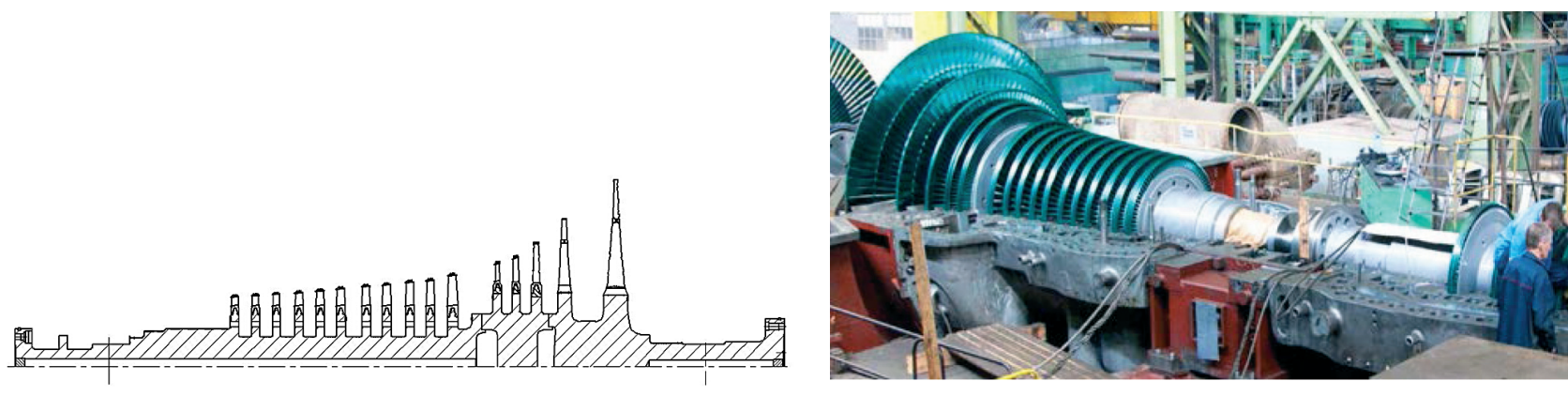

Рис. 7. Ескіз «композитного» ротора; «композитний» ротор на заводському стенді

\section{Науково-технічні розробки для забезпечення міцності і динаміки ротора}

Ротор турбіни важливий з точки зору безпеки AEC або TEC, в зв'язку з чим актуальними залишаються питання забезпечення їх міцності.

Забезпечення експлуатаційної надійності роторів, які працюють у винятково важких умовах, $є$ складною науково-технічною задачею. Ротори турбін піддаються навантаженню від лопаткового апарату, відчувають значні крутні зусилля, працюють в умовах циклічних навантажень при вібрації і крутильних коливаннях і експлуатуються в умовах високих температур. На основі досвіду проектування, виробництва і експлуатації парових турбін можна виділити основні фактори, що визначають надійність роторів.

Для роторів високого і середнього тиску до факторів, що визначають їх надійність, слід віднести: вичерпання тривалої міцності в умовах повзучості при роботі в області високих $500-550^{\circ} \mathrm{C}$ температур; накопичення втомних дефектів в металі роторів внаслідок спільної дії механізмів втоми і повзучості; втомного підростання дефектів в зоні низьких температур від знакозмінних зусиль при обертанні, що призводить до крихких руйнувань.

Визначаючими надійність факторами для роторів НТ є такі: крихке руйнування від дії відцентрових сил; корозійне розтріскування; втомне руйнування при дії знакозмінних напружень при обертанні, згинних і крутильних коливаннях.

Оцінка впливу експлуатаційних факторів на показники короткочасної, довготривалої міцності і довговічності зварних роторів парових турбін i врахування отриманих даних при проектуванні становить основну задачу науково-технічного забезпечення розрахунків динаміки і міцності роторів.

Проектування і доведення роторів включає в себе комплекс розрахунково-теоретичних і експериментальних досліджень, основними 3 яких $€$ наступні:

- розрахунки на міцність в пружній і пружнопластичній областях деформування роторів, що обертаються, під дією відцентрових сил з оцінкою запасів міцності;

- визначення динамічних характеристик роторів при вільних і вимушених згинальних усталених коливаннях та критичних швидкостей обертання;

- розрахунки перехідних крутильних коливань валопровода при різних видах короткого замикання в генераторі з оцінкою багато- і малоциклової втоми;

- розрахунковий аналіз сейсмостійкості елементів і вузлів роторної і статорної частин турбоагрегату в системі турбоагрегат-фундамент-основа при землетрусах;

- визначення вібраційних характеристик роторів;

- оцінка тривалої міцності і повзучості дисків та роторів.

Для проведення розрахунків роторів турбін на етапі їх проектування і доведення створені оригінальні проблемно-орієнтовані програмні розробки в ІПМаш ім. А.М. Підгорного НАН України, в НТУ «ХПІ», а також використані універсальні програмні комплекси, поширювані на міжнародному ринку програмних продуктів.

\section{Технологічні особливості виготовлення зварних роторів}

Ротори відносяться до найбільш відповідальних вузлів. Технології ї виготовлення, і зокрема зварювання, в процесі розробки проходять тривалий цикл досліджень, випробувань і апробацій 3 метою гарантованого забезпечення якості як зварних з'єднань, так і ротора в цілому для забезпечення запроектованої працездатності, надійності та відпрацювання проектного ресурсу.

Складання - зварювання «швидкохідних» роторів здійснюється у вертикальному положенні. Далі ротор встановлюється в горизонтальне положення на спеціальний стенд зварювання (рис. 8). Після закінчення зварювання ротор нагрівається до $400^{\circ} \mathrm{C}$, звільняється від оснащення, обгортається азбестовим полотном для теплової ізоляції і транспортується для встановлення в електропіч для проведення після зварювальної термообробки. 

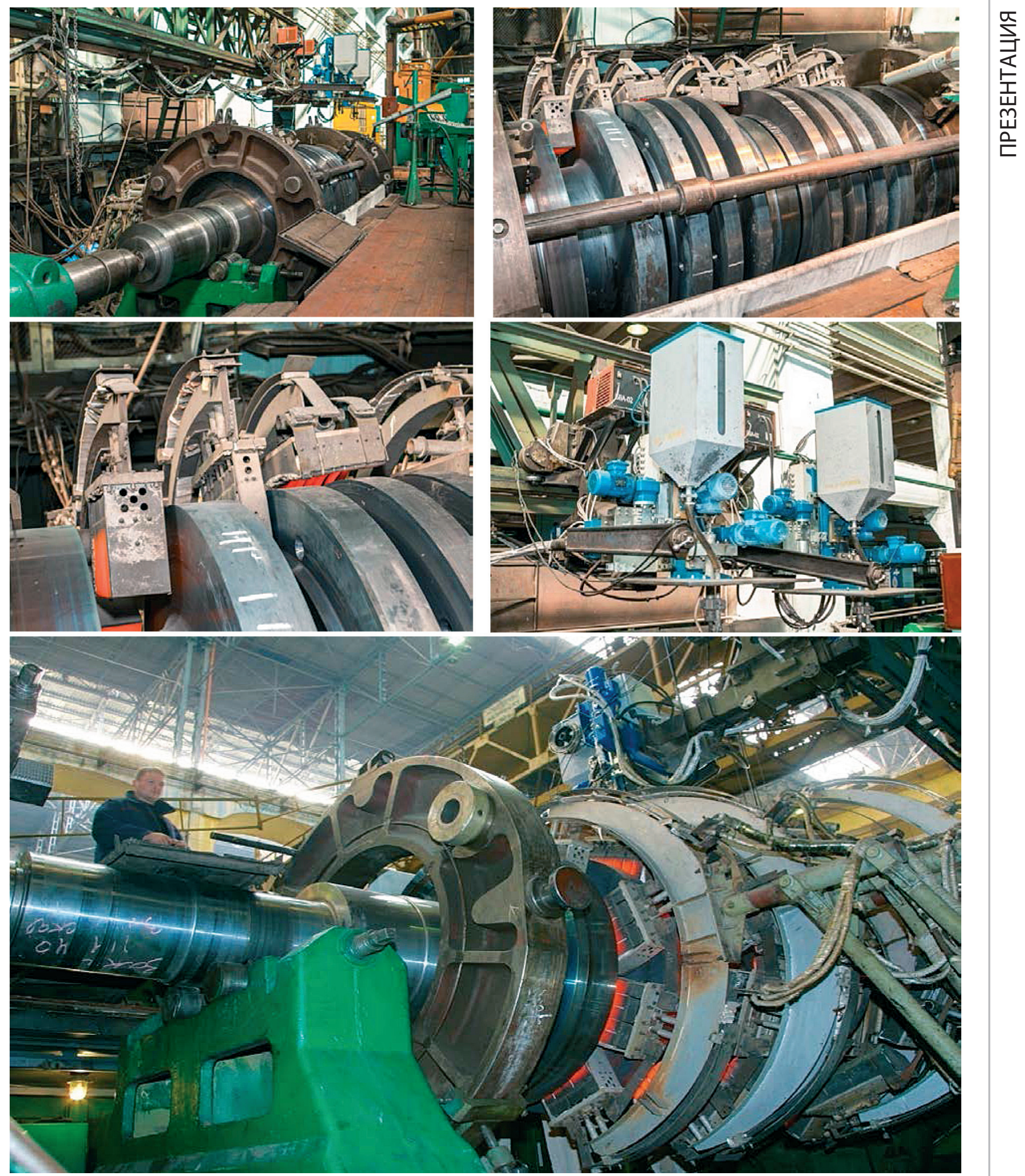

Рис. 8. Стенд зварювання «швидкохідних» роторів і його оснащення

Складання і зварювання «тихохідних» роторів на відміну від «швидкохідних», здійснюються в одному стенді при горизонтальному розташуванні вісі ротора (рис. 9). Усі виготовляємі зварні ротори після виконання термічної і попередньої механічної обробки проходять процедуру контролю якості зварних швів.

Механоскладальне виробництво АТ «Турбоатом» становить близько $65 \%$ від загального обсягу робіт 3 виробництва обладнання (рис. 10-12). 


\section{ТЕхнологиччески TC 2/2019}
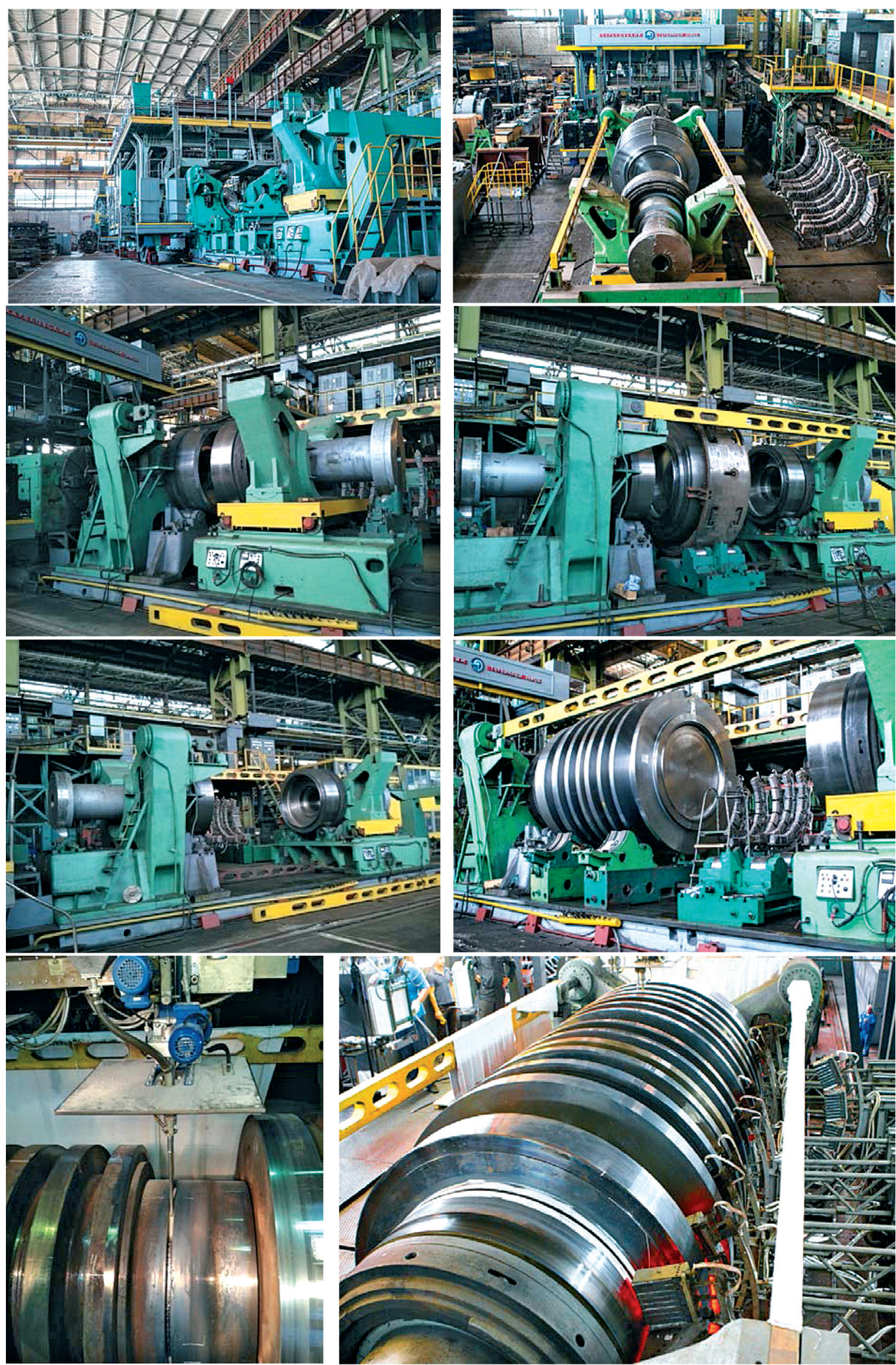

Рис. 9. Етапи складання та зварювання «тихохідних» роторів 


\section{2/2019}

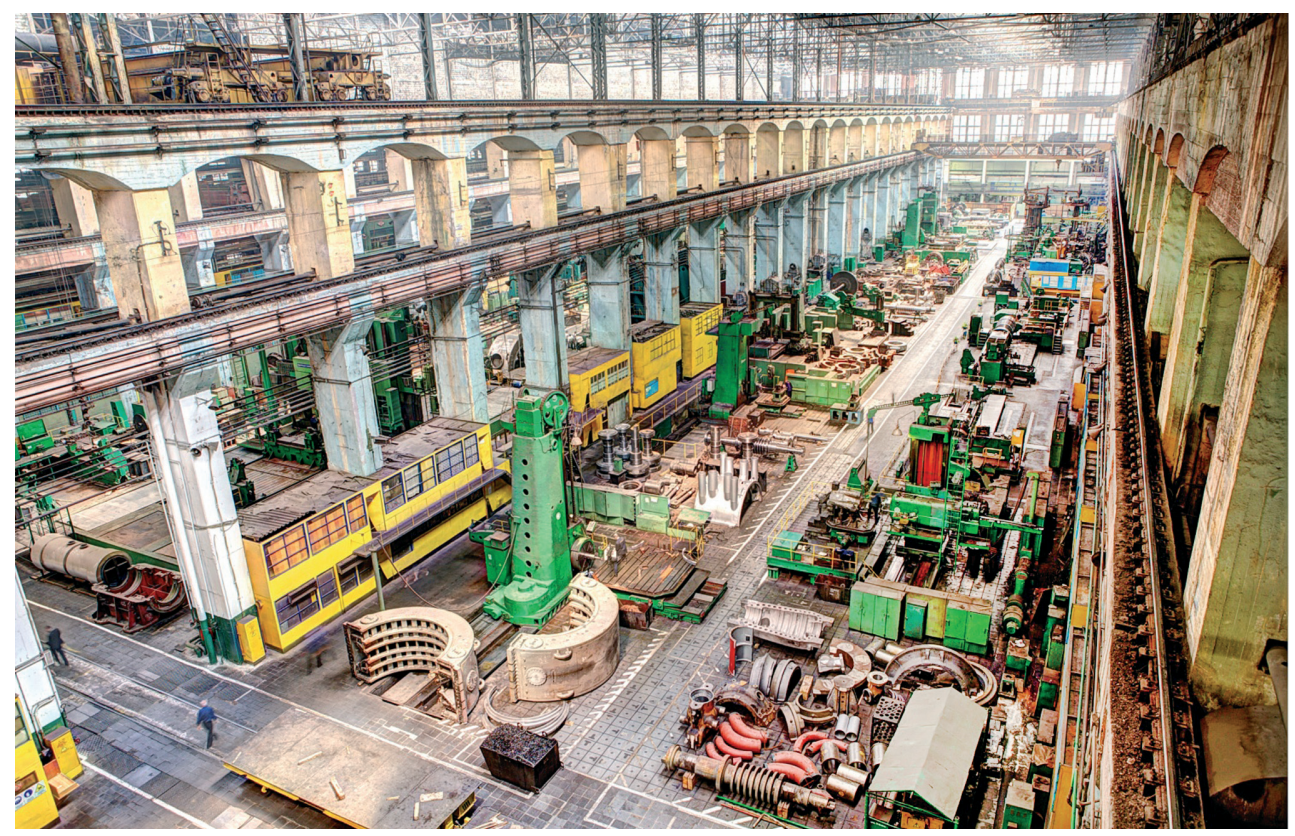

Рис. 10. Дільниця механічної обробки деталей парових турбін

Виробництво забезпечене обладнанням для виконання робіт по точінню, фрезеруванню, розточуванню, свердлінню, шліфуванню, нарізанню зубів, дрібоструминного очищення і фарбування, складання та випробування. Виготовлення дисків для комплектування ротора виконується на токарно-карусельних верстатах с технічними характеристиками, які забезпечують виготовлення всіх їх типів і розмірів.

Обробка роторів парових турбін проводиться на унікальних токарних верстатах, у тому числі $з$ числовим програмним управлінням фірми "Hoesch", з максимальною вагою ротора до 200 тонн. Для обробки радіусних ялинкових пазів в роторах під установку лопаток використовуються спеціальні 2-стійкові роторно-фрезерні верстати.
При цьому передбачена одночасна робота обома стійками при обробці пазів 2 однойменних дисків ротора (рис. 13). Верстат обладнаний двома силовими стояками, що допускає одночасну обробку двох дисків ротора. Поворот ротора на кут цілого кроку виконується механізмом ділильної головки 3 точністю до 5 кутових секунд.

Важливий вплив на забезпечення надійної експлуатації роторів і лопаточного апарату надає якість складеню ступеню при монтажі (рис.14).

Побудовано та введено в експлуатацію складально-випробувальний корпус з вакуумними камерами «Schenck» ДН-10 і ДН-13 для динамічного балансування роторів (рис. 15), лабораторними базами, складальними стендами, дільницями механічної обробки і облопачування роторів парових турбін.

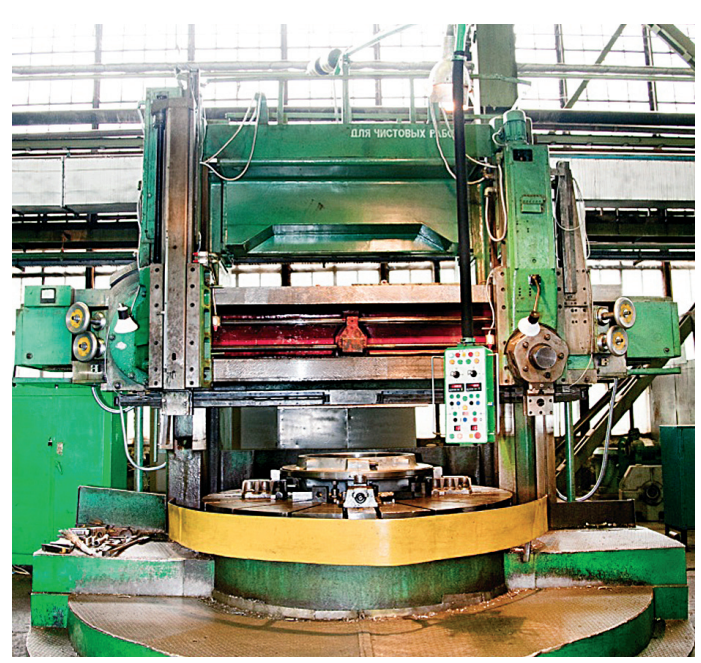

Рис. 11. Токарно - карусельний верстат

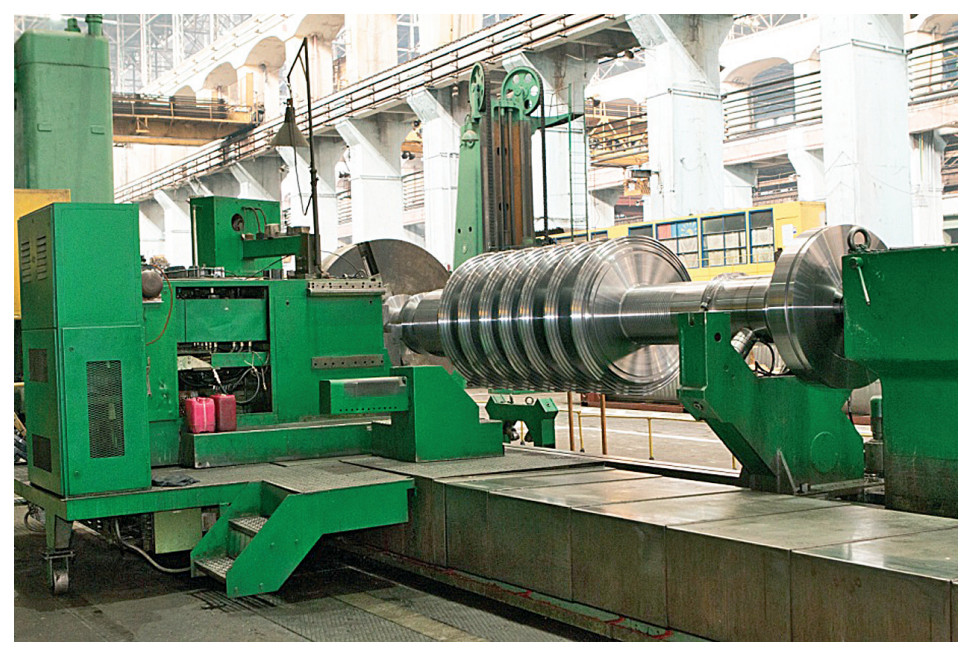

Pис. 12. Механічна обробка ротора на верстаті «Hoesch» 


\section{TixнологтическиE TC 2/2019 \\ СИСТЕMЫ TC}

梠
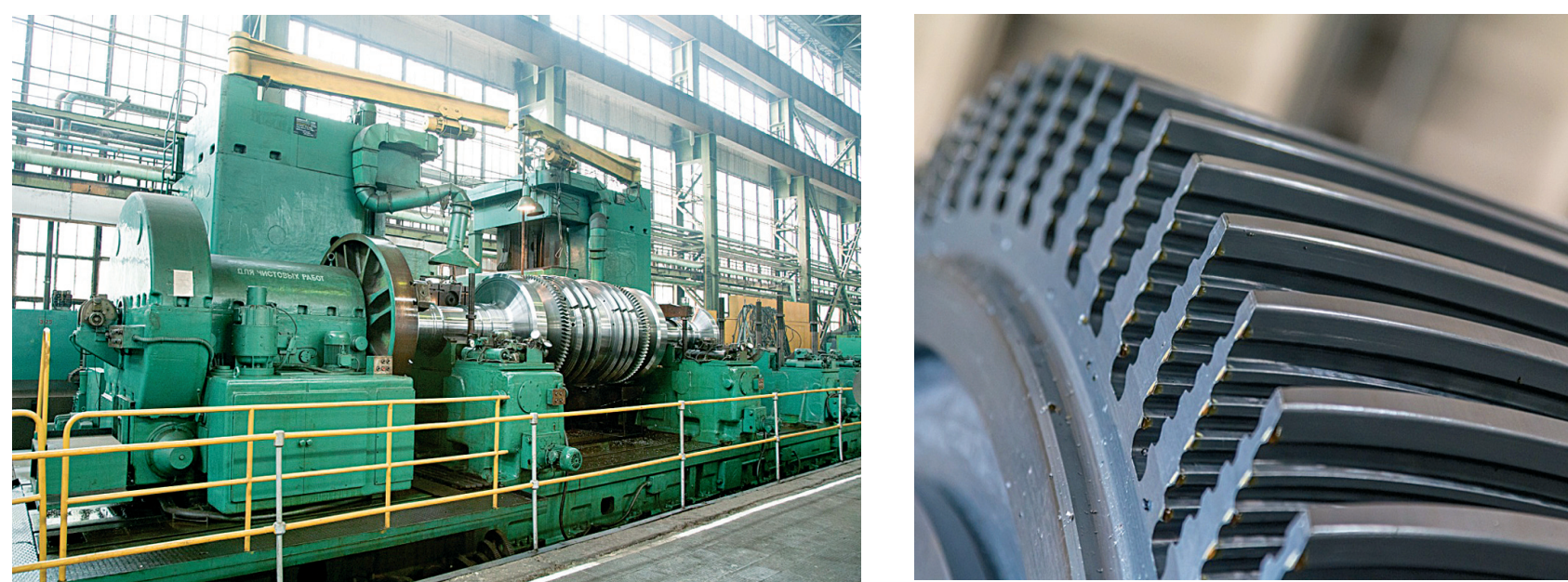

Рис. 13. Обробка радіусних ялинкових пазів в роторах під установку лопаток

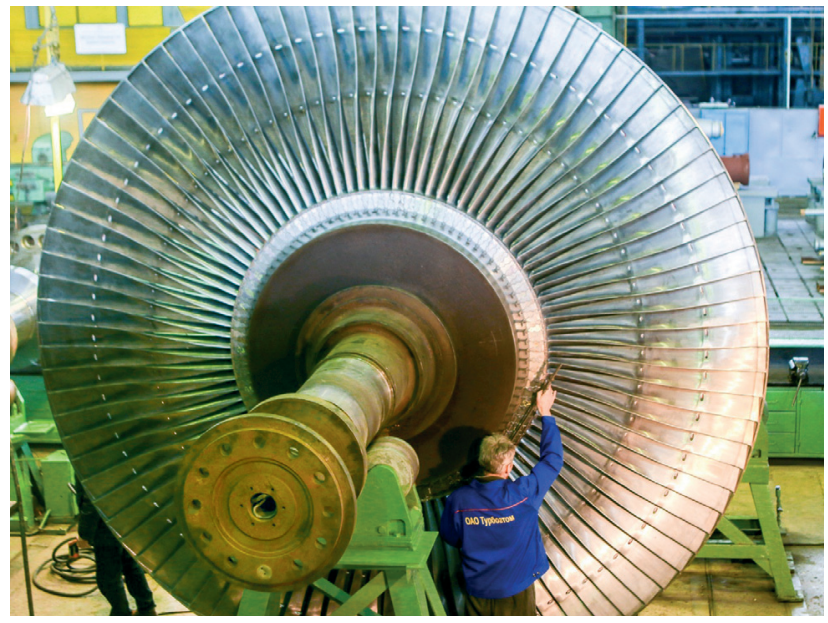

Рис. 14. Складання робочих лопаток з титанового сплаву на диску

Розробка і постачання роторів для електростанцій України в рамках завдань імпортозаміщення

На AEC і TEC України знаходяться в експлуатації турбіни виробництва ЛМЗ, що входить до

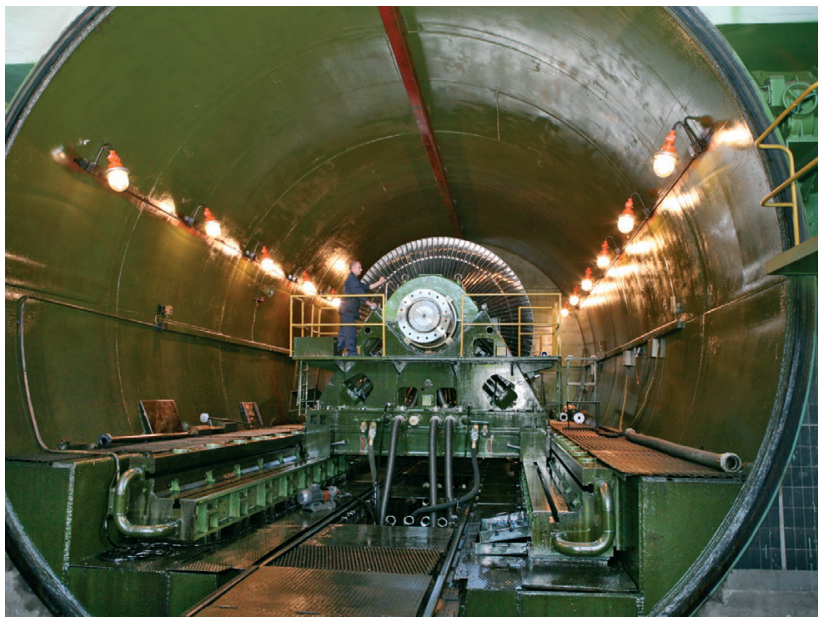

Рис. 15. Установка ротора для динамічного балансування ротора в вакуумній камері

складу АТ «Силові машини» (Росія), сумарною потужністю біля 13 млн кВт, зокрема, п'ять турбін К-1000-60/3000 на AEC, 43-і турбіни К-200-130 на TEC. Проточні частини турбін на сьогоднішній день є морально і фізично застарілими і вимагають відновлення.

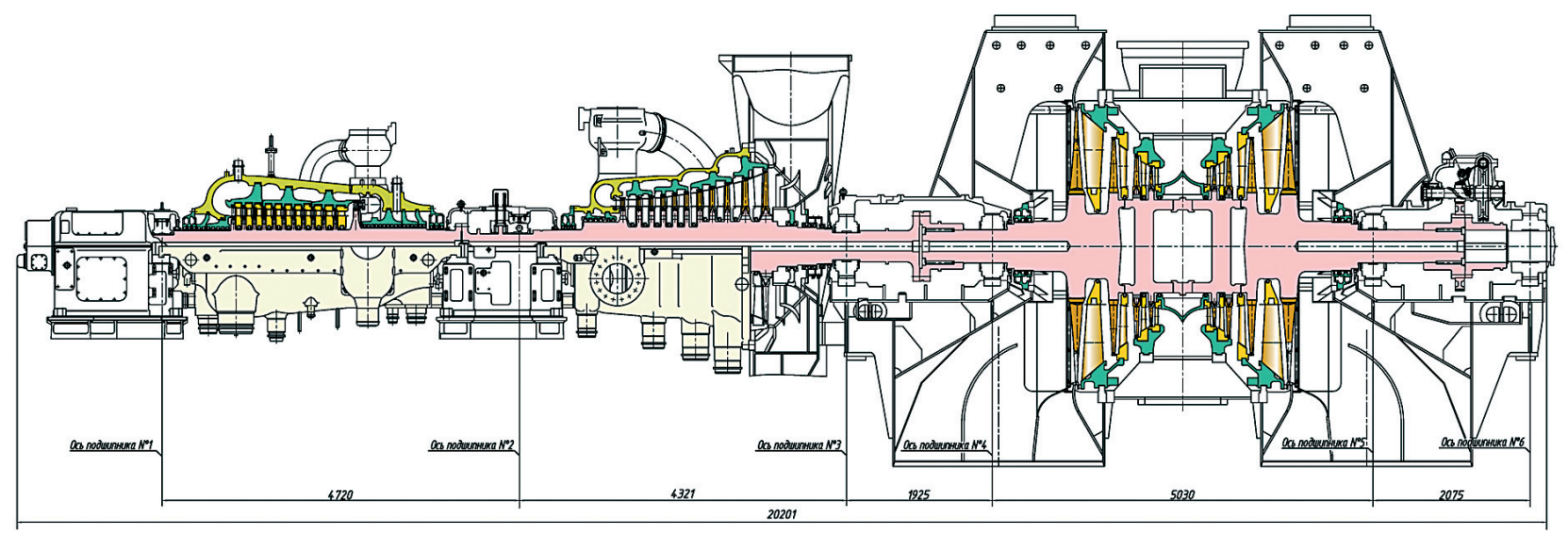

Рис. 16. Подовжній розріз модернізованої турбіни типу К-200-130 


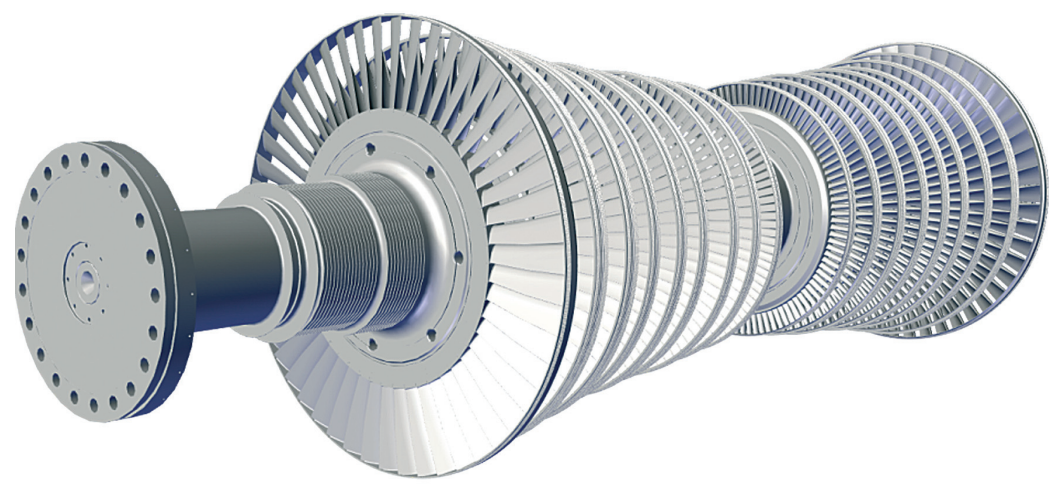

Рис. 17. 3-D модель ротора середнього тиску виробництва AT «Турбоатом»

Модернізація циліндра ВТ турбіни К-100060/3000 дозволяє забезпечити на турбіні підвищення потужності, підвищення економічності, збільшення міжремонтного періоду до 6 років, збільшення терміну служби до 60 років.

АТ «Турбоатом» виконує модернізацію турбін виробництва ЛМЗ не тільки на атомних станціях, a і на теплових. За останні 13 років на ТЕС України виконана різного об'єму модернізація проточних частин 13-и з 43-х парових турбін типу К-200-130 виробництва ЛМЗ. АТ «Турбоатом» пропонує і виконує заміну циліндрів високого тиску і середнього тиску з новими проточними частинами, а також модернізацію циліндра низького тиску. При цьому виконується заміна роторів виробництва ЛМЗ на ротори виробництва АТ «Турбоатом» (рис. 16).

Турбіна К-800-240-2 Слов'янської ТЕС бл. №7 виробництва ЛМЗ працює з грудня 1971р. і до теперішнього часу напрацювання становить 200000 год, що значно перевищує розрахунковий ресурс експлуатації вузлів і деталей турбін і вимагає їі відновлення.

В даний час виконуються роботи по виготовленню циліндра середнього тиску для заміни циліндра середнього тиску виробництва ЛМЗ який виробив ресурс. В 2018 році АТ «Турбоатом» замовило всі необхідні матеріали та приступило до виконання модернізації циліндра середнього тиску i, в першу чергу, до виготовлення ротора (рис.17) та його елементів.

Для забезпечення подальшої експлуатації турбіни і поліпшення техніко-економічних показників надійності, економічності і ремонтопридатності, пропонується виконати модернізацію проточної частини циліндрів високого та низького тисків турбіни.

При необхідності подібну модернізацію парових турбін з заміною роторів можна виконати на блоках № 5-7 Вуглегірської та Запорізької ТЕС.

\section{Висновки}

За роки своєї діяльності АТ «Турбоатом» виготовило велику кількість роторів різного конструктивного і технологічного виконання для потужних парових турбін, які встановлені на теплових і атомних електростанціях як в Україні, так і в інших країнах світу.
Позитивний досвід проектування і виготовлення у великій кількості надійних роторів турбін з високоефективним облопаченням є результатом плідної співпраці з науковцями провідних науково-дослідних інститутів та університетів України (НТУ «XПI», IE3 ім. С. О. Патона НАН України, ІПМаш ім. А. М. Підгорного НАН України). В результаті спільної роботи було створено науково-технічне забезпечення проектних досліджень, представлене рядом методик та математичних моделей.

За останні 10 років в АТ «Турбоатом» виконані розробки, проектування і виробництво понад 45 роторів для швидкохідних турбін К-325-23.5, К-330-23.5, К-200-130 ТЕС України, Казахстану, К-220-44 Вірменської АЕС, К-240-4.0 для АЕС Кайга і Раджастан, Індія, та тихохідних турбін К-1000-60/1500-2М Хмельницької АЕС.

Ефективність нових роторів була підтверджена експлуатацією їх на енергоблоках АЕС та ТЕС України.

\section{Література}

[1] Енергетична стратегія України на період до 2035 року. «Безпека, енергоефективність, конкурентоспроможність», КМУ, № 605-р, 2017, 66 с.

[2] О.К. Морачковський, В.В.Дмитрик, О. П. Усатий, Б. П. Зайцев, В.Ю. Скульський, М.М. Гришин, Ю.Г. Пащенко, О.Г. Кантор, О.В. Коноваленко. Створення роторів турбін великої потужності: монографія. Харків: ФОП Панов А.М., 2018. 224 с.

[3] Программа участия АО «Турбоатом» в поставках оборудования для АЭС Украины на 5-летний период (2018-2022 гг.). НАЭК «Энергоатом», 2017, 3 с.

[4] Суботін В.Г. Парова турбіна нового покоління потужністю 325 МВт для модернізаціі турбоагрегатів К-325-240. В.Г Суботін, Є.В. Левченко, В.Л. Швецов, О.М. Нагорський, М.А. Борисов. Новини енергетики. 2009. № 3.

[5] Левченко Е.В., Гришин Н.Н., Аркадьев Б.А., Сухинин В.П. Сварные роторы турбоагрегатов. Теплоэнергетика. 1998. №1. С. 40-43. 
Shvetsov V. L., Grishin M. M.

TURBOATOM, JSC. Ukraine, Kharkiv

\section{DEVELOPMENT OF ROTORS FOR HIGH-POWER TURBINES}

The scientific and technical foundations of the development and implementation of operationally reliable, high-performance rotors for high-power new-generation turbines are considered, as ready-to-use finished products with a large component of $R \mathcal{E} D$ and innovation, which may be used both for upgrading existing turbine units and for supplying new steam turbine units with a capacity of 100 to 1250 MW to TPPs, CHPs and NPPs in Ukraine and for export. The designs of the created rotors correspond to the best world practices in terms of their performance, reliability and safety indicators. [dx.doi.org/10.29010/

Keywords: steam turbine; solid-forged rotors; combined welded rotors; strength; turbine unit; short circuit; shafting; modernization; weld bench.

\section{References}

[1] Energetichna strategija Ukraïni na period do 2035 roku. «Bezpeka, energoefektivnist, konkurentospromozhnist», KMU, № 605-r, 2017, 66 p.

[2] Morachkovs'kij O. K., .Dmitrik V.V, Usatij O. P., Zajcev B. P., Skulskij V.Ju., Grishin M. M., Pashhenko Ju. G., Kantor O. G., Konovalenko O. V.. Stvorennja rotoriv turbin velikoji potuzhnosti: monografija. Harkiv: FOP Panov A. M., 2018. 224 p.

[3] Programma uchastija AO «Turboatom» v postavkah oborudovanija dlja AJeS Ukrainy na 5-letnij period (20182022 gg.). NAJeK «Energoatom», 2017, 3 p.

[4] Subotin V. G. Parova turbina novogo pokolinnja potuzhnistju 325 MVt dlja modernizacii turboagregativ K-325-240. V. G. Subotin, E. V. Levchenko, V. L. Shvecov, O. M. Nagorskij, M. A.Borisov. Novini energetiki. 2009. № 3.

[5] Levchenko E. V., Grishin N. N., Arkadev B. A., Suhinin V. P. Svarnye rotory turboagregatov. Teplojenergetika. 1998. №1. Pp. 40-43. 